\title{
Exploring selected plant nutrient in compost prepared from food waste and cattle manure and its effect on soil properties and maize yield at Wondo Genet, Ethiopia
}

\author{
Kebede Wolka* and Bezashwork Melaku
}

\begin{abstract}
Background: Unsafe and non-productive disposal of food waste pollutes the environment. Biodegradable food wastes have been composted and applied to soil as an amendment to improve the soil properties and fertility while improving environmental safety. In the Wondo Genet College of Forestry and Natural Resources compound, food wastes are unsafely deposited attracting wild animal who scavenge around the residence and cafeteria areas. This study analyzes selected plant nutrient in compost prepared from a mixture of food waste and cattle manure, and how the addition of the compost affects soil properties and crop yield.

Results: Total nitrogen and organic carbon levels declined significantly after 70 days of applying compost and commercial fertilizer to soil due to leaching and erosion loss. No significant changes were observed in the other soil parameters. Significantly high maize yield was observed in plots treated with compost prepared by mixing $50 \%$ food waste with $50 \%$ cattle manure by volume (50FW50M) compared to the control and all other treatments. The compost prepared by mixing $25 \%$ food waste with $50 \%$ cattle manure by volume (25FW75M) showed significantly higher yield than compost prepared only from food waste (100FW) and the control.

Conclusion: Instead of dumping food waste and creating scavenging opportunity for wild animals and possible health issues for residents, the material should be converted to compost in the 50FW50M proportion. The cost benefit for this specific situation should be analyzed in future study and the compost should be tried on other crops besides maize.
\end{abstract}

Keywords: Biodegradable waste; Crop yield; Pollution; Scavenging wild animals; Soil property

\section{Background}

Large quantities of various organic wastes are generated continuously from both point and non-point sources. Food waste, which includes unused consumable food items and rejected products from food manufacturing and processing industries, create significant organic waste in urban areas and food processing locations. Food wastes are produced in high volume and tend to increase with human population (Mrabet et al. 2012). Improper disposal of increasing food waste due to increasing population causes ever-increasing problems in environmental

\footnotetext{
* Correspondence: kebedewolka@gmail.com

Wondo Genet College of Forestry and Natural Resources, School of Natural Resources and Environmental Studies, Hawassa University, P.O.Box 128,
} Shashemene, Ethiopia

pollution and disease occurrence to both human beings and animals. These improperly managed wastes can have negative impacts on human and environmental health during the decomposition process. Therefore, composting of food waste has recognized benefits for reducing volume of household waste for landfills (Colon et al. 2010; Anderson et al. 2012; Mrabet et al. 2012; Benjawan et al. 2015) and significantly improves soil properties and land productivity. On other hand landfill by itself requires space and the compounds released by this processes pollute air, soil and water (Benjawan et al. 2015). Soil and ground water can be contaminated, negatively influencing soil quality and aquatic ecosystems. Neighborhood pride is affected due to unpleasant appearances and smells. 
Playgrounds become unsafe for children due to diseasecausing contaminated materials.

A large amount of organic waste is either burned or buried in landfills; with both treatments causing environmental pollutants. There are a number of micro and macro organisms that have the ability to naturally convert organic waste into valuable plant nutrients and organic matter; items critical for maintaining soil productivity. Organic waste, which is otherwise discarded, can be composted and converted into productive uses such as soil amendments (Barral Silva et al. 2007). At the same time that this potential soil amendment is being thrown away, farmland soils are degrading, showing a progressive productivity decline. Intensive soil cultivation causes a reduction in soil organic matter (Giannakis et al. 2014) and influences soil properties (Hartl and Erhart 2005). Due to poor soil management and related problems, Ethiopia faces major plant nutrient depletion (Tulema et al. 2007).

Organic-based agricultural production is a rapidly emerging technology which partly solves waste disposal problems, through conversion of biodegradable wastes into organic fertilizer, which can be used for crop production. The fertilizer contributes to rehabilitating and sustaining the fertility of our croplands that have been degraded, or are in danger of degradation, due to intensive crop production and improper soil management practices. Compost improves soil quality and productivity, reduces the need for chemical fertilizers, and can prevent and control erosion.

Composting converts fresh, biodegradable, organic wastes and animal manure to a stable form of organic matter, such as humus. Composting is a versatile technique for converting biodegradable material to organic matter that can be applied to soil (Gajalakshmi and Abbasi 2008). It can be considered as an important source of organic matter (Szilveszter et al. 2012). Organic fertilizers can improve various soil properties related to organic matter (Reeves 1997; Tulema et al. 2007). It can increase the water holding capacity of soils, and can improve structure and water movement through heavier textured soils that are high in silt and clay content. By increasing the organic content of the soil, biological activity can be enhanced. Water and nutrient holding capacity can be improved in some soils. Some compost has the ability to suppress fungal diseases and soil borne disease (Gajalakshmi and Abbasi 2008). Compost amendments to soil increased organic matter, and N, P and $\mathrm{K}$ content of soil, implying improved biomass production and nutrient uptake (Gajalakshmi and Abbasi 2008; Szilveszter et al. 2012 Miller et al. 2015). It is a technology which has benefit-cost ratio higher than 1 (Gajalakshmi and Abbasi 2008).

The quality of compost itself vary with type of raw materials used, management of composting processes, stage of decomposition processes, type of nutrients applied to enrich the compost and/or to enhance decomposition. Compost prepared by mixing cow dung with paddy straw showed higher total organic matter, $\mathrm{C} / \mathrm{N}$ ratio, but higher phosphorus, nitrogen, zinc and manganese for composts enriched with nitrogen or phosphorus (Hussain et al. 2015). On other hand, the compost enrichment with urea, phosphate, zinc, iron, copper and manganese at various stages of composting in chaffed cotton stalks and farm wastes reduced $\mathrm{C} / \mathrm{N}$ ratio, and lignin but increased other nutrients Chari and Ravi (2013). The compost produced from poultry litter showed higher phosphorus, potassium, calcium and magnesium compared to fresh manure (Faridullah et al. 2014). Some food waste compost may contain significant quantity of heavy elements such as lead, nickel, zinc, manganese, copper, chromium (Hseu, 2004). After complete decomposition, the household waste compost also contain significant proportion of plant nutrients and soil properties amending constituents (Mrabet et al. 2012).

Agriculturalists and environmentalists have an increasing interest in converting municipal solid waste to compost that contributes to soil fertility and crop productivity (Giannakis et al. 2014). In addition to soil amendment, composting food scraps reduces green house gas emissions such as carbon dioxide $\left(\mathrm{CO}_{2}\right)$, methane $\left(\mathrm{CH}_{4}\right)$ and nitrous oxide $\left(\mathrm{N}_{2} \mathrm{O}\right)$. The Intergovernmental Panel on Climate Change (IPCC) has identified organic waste as a key contributor to climate change, releasing $7 \%$ of total gas emissions in developing countries. This amount is predicted to increase with population growth. Utilizing compost in agriculture supports climate change mitigation in two ways: directly through carbon sequestration and enhanced plant growth; and indirectly from reduced production and use of chemical fertilizers and pesticides that generates green house gases and cause a variety of other environmental issues.

In the Wondo Genet College of Forestry and Natural Resources compound, where this study was carried out, cafeteria and household food wastes have been deposited in unregulated and unauthorized places. This creates opportunity for wild animals (monkey, apes, wild boars, birds, etc.) to scavenge the material and become accustomed to this food source. Wildlife biologists state that human food is not necessarily good for wild animals (Roberta 1999). Excessive intake of these foods may interfere with digestion. Discarded food can become contaminated with microorganisms that cause food poisoning. At the very least, the wild animals will become accustomed to free handouts and be unprepared to hunt for themselves if the human food is cut off. At the college, significant volumes of food wastes are produced daily, but little study concerning the productive utilization and safe disposal mechanisms for this material has been implemented. The 
plant nutrient content of the compost prepared from food wastes has not been sufficiently studied to suggest a more productive use for it besides threatening the health of wild animals and degrading environmental quality. Therefore, objectives of this study were: (1) to analyze selected plant nutrient in compost prepared from food waste and cattle manure; (2) to investigate effects of this compost on selected soil properties; and (3) to analyze its effect on maize crop yield in field condition.

\section{Results and discussion}

\section{Compost quality}

The electric conductivity (EC) of the compost collected from the various treatments ranged from 2.51 to 4.02 . The compost $\mathrm{pH}$ was slightly basic and not significantly different among the treatments. The organic carbon $(\mathrm{OC})$, primary plant nutrients $(\mathrm{AK}, \mathrm{AP}$, and $\mathrm{TN})$ and cation exchange capacity (CEC) also showed no significant difference among treatments (Table 1).

The observed compost $\mathrm{pH}$ and $\mathrm{EC}$ in all treatments satisfies the standard set for quality compost (Alexander, 2001). This implies, that in reference to $\mathrm{pH}$ and $\mathrm{EC}$, the various proportions of composting materials produced favorable plant-growing compost. The concentrations of $\mathrm{AP}, \mathrm{AK}$ and $\mathrm{TN}$ in the compost is essential, as these plant macro-nutrient must be available if compost is to replace the need for synthetic fertilizer (Alexander, 2001). In all compost treatments, the AP and AK exist in comparatively high concentration, but $\mathrm{TN}$ is low. The presence of decomposing material and the loss of volatile components (such as ammonia) during the composting process can contribute to these observed results.

One of the benefits of compost, is the input of carbon based material, such as organic carbon (Gajalakshmi and Abbasi 2008; Szilveszter et al. 2012) which has a significant role in soil health and plant growth (Brady and Weil 2002). According to the recommended standard by Alexander (2001), the observed OC in all treatments, satisfy the required range. The carbon based material in soil improves the CEC and CEC influences soil media $(\mathrm{pH})$ and cation adsorption capacity (usually higher CEC is preferred). The results in this experiment satisfy the required CEC value for matured compost prepared from household refused material (Gajalakshmi and Abbasi 2008).

\section{Soil properties after treatment}

After 70 days of applying the soil treatment, the soil test showed varying results. The EC did not show statistically significant difference among treatments. In all cases, it was between 0.04 to $0.06 \mathrm{ds} / \mathrm{m}$, with the lower figure (0.04) for treatment 50FW50W and commercial fertilizer. The soil pH ranges from 6.14 to 6.32 . The soil organic carbon and plant nutrient concentration indicating parameters $\mathrm{AK}, \mathrm{AP}, \mathrm{TN}, \mathrm{OC}$ and $\mathrm{CEC}$ showed no significant difference among treatments (Table 2).

Even though compost containing comparatively higher AK (Table 1) was applied, the observed AK after treating the soil with compost and synthetic fertilizer was not significantly different compared to pre-treatment levels. Lower AK was observed in soil analyzed at different intervals, before and after applying the treatment (Table 3). After applying various treatments, there was no significant difference among the treatment and control plots. The possible reasons for this are: AK has been taken up by the plants, and its susceptibility for leaching and erosion loss (Brady and Weil, 2002). The observed equilibrium of $\mathrm{AK}$ in soil before and after treatment indicates high concentrations of AK compared to the set standards (Horneck et al. 2011).

The AP in compost (Table 1) appears much greater than the AP in soil after compost application. Amendment of soil with compost increases soil phosphorous (Eichler-Löbermann et al. 2007). However, AP levels in soil before compost application compared to post-application levels showed no significant difference. This might be due to rapid phosphorus fixation (change of available phosphorus to unavailable form) in the compost and fertilizer (Brady and Weil 2002). The TN and OC were not significantly different among treatments and their overall concentration was minimal due to erosion and leaching. Even though the CEC in compost appears high (Table 1), its

Table 1 Compost quality

\begin{tabular}{|c|c|c|c|c|c|}
\hline \multirow[t]{2}{*}{ Parameters } & \multicolumn{4}{|c|}{ Treatment (mean $\pm \mathrm{SD})$} & \multirow[t]{2}{*}{$p$-value } \\
\hline & $100 \mathrm{FW}$ & 75FW25M & 50FW50M & 25FW75M & \\
\hline$\overline{E C}(\mathrm{dS} / \mathrm{m})$ & $4.02 \pm 0.41$ & $3.19 \pm 0.62$ & $2.51 \pm 0.42$ & $2.83 \pm 1.40$ & 0.21 \\
\hline $\mathrm{pH} \mathrm{1:2:5}$ & $7.67 \pm 1.06$ & $7.79 \pm 0.40$ & $7.83 \pm 0.70$ & $7.62 \pm 0.29$ & 0.975 \\
\hline AK (cmol (+)/Kg Soil) & $27.07 \pm 9.24$ & $26.64 \pm 4.05$ & $21.63 \pm 4.23$ & $21.74 \pm 6.42$ & 0.595 \\
\hline AP $(\mathrm{mg} / \mathrm{Kg})$ & $676.67 \pm 200.24$ & $385.67 \pm 190.08$ & $694.67 \pm 95.02$ & $663.67 \pm 204.80$ & 0.997 \\
\hline TN (\%) & $1.94 \pm 0.40$ & $1.63 \pm 0.13$ & $1.51 \pm 0.13$ & $1.41 \pm 0.72$ & 0.488 \\
\hline OC (\%) & $33.16 \pm 3.93$ & $31.36 \pm 1.70$ & $31.08 \pm 3.59$ & $31.35 \pm 2.13$ & 0.820 \\
\hline CEC (cmol (+)/Kg Soil) & $60.87 \pm 6.18$ & $61.05 \pm 4.01$ & $62.14 \pm 4.01$ & $60.51 \pm 2.20$ & 0.970 \\
\hline
\end{tabular}


Table 2 Soil properties after applying various treatments

\begin{tabular}{|c|c|c|c|c|c|c|c|}
\hline \multirow[t]{2}{*}{ Parameters } & \multicolumn{6}{|c|}{ Treatment $($ mean \pm SD) } & \multirow[t]{2}{*}{$p$-value } \\
\hline & $100 \mathrm{FW}$ & 75FW25M & 50FW50M & 25FW75M & Control & Commercial fertilizer & \\
\hline$\overline{E C}(\mathrm{dS} / \mathrm{m})$ & $0.05 \pm 0.02$ & $0.06 \pm 0.00$ & $0.04 \pm 0.01$ & $0.06 \pm 0.01$ & $0.05 \pm 0.02$ & $0.04 \pm 0.00$ & 0.33 \\
\hline $\mathrm{pH} 1: 2: 5$ & $6.16 \pm 0.11$ & $6.14 \pm 0.06$ & $6.32 \pm 0.17$ & $6.27 \pm 0.12$ & $6.29 \pm 0.17$ & $6.18 \pm 0.14$ & 0.99 \\
\hline AK (cmol (+)/Kg Soil) & $0.79 \pm 0.29$ & $0.68 \pm 0.07$ & $0.58 \pm 0.12$ & $0.73 \pm 0.25$ & $0.71 \pm 0.15$ & $0.62 \pm 0.16$ & 0.30 \\
\hline AP $(\mathrm{mg} / \mathrm{Kg})$ & $12.15 \pm 1.24$ & $9.27 \pm 4.16$ & $7.01 \pm 3.29$ & $8.49 \pm 4.56$ & $4.62 \pm 2.36$ & $6.56 \pm 1.13$ & 0.13 \\
\hline TN (\%) & $0.16 \pm 0.04$ & $0.16 \pm 0.03$ & $0.17 \pm 0.03$ & $0.14 \pm 0.02$ & $0.15 \pm 0.03$ & $0.18 \pm 0.05$ & 0.69 \\
\hline OC (\%) & $1.66 \pm 0.40$ & $1.53 \pm 0.23$ & $1.70 \pm 0.31$ & $1.39 \pm 0.20$ & $1.25 \pm 0.29$ & $1.78 \pm 0.50$ & 0.43 \\
\hline CEC (cmol (+)/Kg Soil) & $15.49 \pm 1.62$ & $14.86 \pm 2.82$ & $17.32 \pm 1.37$ & $15.15 \pm 2.58$ & 15.003 .83 & $17.82 \pm 1.06$ & 0.54 \\
\hline
\end{tabular}

level after treatment did not change (Table 3). There was no significant difference among treatments as the CEC of soil is possibly buffered.

\section{Effects on soil quality}

Soil properties before treatment (application of treatment to test crop yield and soil properties) compared with soil properties after treatment showed varying results. The CEC showed no statistical change. Even though statistically insignificant, the soil EC and AK showed slight increases and AP decreased after treatment application. Total nitrogen and organic carbon became significantly lower after treatment compared to before treatment.

Previous studies are in line with these findings. A 60 year experiment by Oberholzer Han et al. (2014) reported continuous decline of soil organic carbon on crop land converted from grassland, even though substantial soil management to improve organic matter had been practiced. Giannakis et al. (2014) reported that TN and

Table 3 Comparing soil properties before and after treatment application

\begin{tabular}{llll}
\hline Parameters & Treatment & Mean \pm SD & $p$-value \\
\hline EC $(\mathrm{dS} / \mathrm{m})$ & Before treatment & $0.04 \pm 0.01$ & 0.07 \\
& After treatment & $0.05 \pm 0.01$ & \\
$\mathrm{pH} 1: 2: 5$ & Before treatment & $6.28 \pm 0.12$ & 0.3 \\
& After treatment & $6.22 \pm 0.13$ & \\
AK(cmol (+)/Kg Soil) & Before treatment & $0.67 \pm 0.17$ & 0.8 \\
& After treatment & $0.69 \pm 0.17$ & \\
$\mathrm{AP}(\mathrm{mg} / \mathrm{Kg})$ & Before treatment & $9.63 \pm 5.40$ & 0.4 \\
& After treatment & $8.02 \pm 3.56$ & \\
$\mathrm{TN}(\%)$ & Before treatment & $0.42 \pm 0.05$ & 0.00 \\
& After treatment & $0.16 \pm 0.03$ & \\
$\mathrm{OC}(\%)$ & Before treatment & $3.73 \pm 0.50$ & 0.00 \\
& After treatment & $1.55 \pm 0.34$ & \\
$\mathrm{CEC}(\mathrm{mg} / \mathrm{Kg})$ & Before treatment & $15.94 \pm 2.64$ & 1.0 \\
& After treatment & $15.94 \pm 2.34$ & \\
\hline
\end{tabular}

SOC gradually decreased in plots treated with compost. The nitrogen decline might be due to leaching, nitrification etc. The organic matter can decline because of erosion and repeated cultivation. Contrary results have been reported, such as compost amendments increasing soil phosphorous (Eichler-Löbermann et al. 2007) and increasing soil carbon and nitrogen (Hepperly et al. 2009; Nguyen and Shindo 2011).

\section{Effects on crop yield}

All treatments showed comparatively better crop yield (kg/ha) than the control plots (Table 4). The yield appeared in decreasing order of 50FW50M, 25FW75M, commercial fertilizer, 75FW25M, 100FW and control. The highest yield was observed in treatment 50FW50M, which was compost with $50 \%$ food waste and $50 \%$ cattle manure. This treatment resulted in significantly higher yield $(p<0.05)$ than the control and all other treatments. The 25FW75M yield was significantly higher $(P<0.05)$ than 100FW and control. Among treatments 100FW, 75FW25M, synthetic fertilizer and control showed no significant difference even though the control has the smallest yield.

Synthetic chemical fertilizer is easy to apply and provides good yield (Hepperly et al. 2009). However, in this study, compost showed a greater yield than synthetic fertilizer. The findings on maize yield in this study agrees with the report by Edwerds et al. (2007)) in which compost application (in 974 plots and on 9 crops including maize) at the rate of 5-15 tons/ha for 7 years, showed

Table 4 The observed crop yield kg/ha after treatment

\begin{tabular}{llll}
\hline S/N & Treatment & Mean \pm SD & $p$-value \\
\hline 1 & 100FW & $2500.00 \pm 1500.00 \mathrm{ab}$ & 0.001 \\
2 & 75FW25M & $2849.21 \pm 753.80 \mathrm{c}$ & \\
3 & 50FW50M & $6761.90 \pm 972.41 \mathrm{acdef}$ & \\
4 & $25 \mathrm{FW} 75 \mathrm{M}$ & $4609.52 \pm 1298.46 \mathrm{bdg}$ & \\
X5 & Control & $1666.67 \pm 520.42 \mathrm{eg}$ & \\
6 & Commercial fertilizer & $2944.44 \pm 838.87 \mathrm{f}$ & \\
\hline
\end{tabular}


greater yields than commercial fertilizer and control (no treatment) in Ethiopia's Tigray region. The study by Rosen and Bierman (2005) suggests combining cattle manure with other composting material for more beneficial use of plant nutrients which in this study showed good yield. Giannakis et al. (2014) indicated cropland amended with compost at rate of 50 and 100 ton/ha resulted in significantly lower yield than tomato plants treated with conventional fertilizer. Another related study also confirms that a four-year compost application significantly and continuously increased dry matter yield of potatoes, fodder beets, forage maize and Brussels sprouts D'Hose et al. (2012). Yet, another study reported higher crop yields by applying compost mixed with fertilizer (Eichler-Löbermann et al. 2007), which indicates the important role of compost in crop yield. A partially contradicting result was reported by Lillywhite et al. 2009, which indicated the application of municipal waste derived compost, resulted in both increased and decreased barley yields, depending on the situation.

\section{Conclusions}

The compost prepared from various proportion of materials (food waste and cattle manure) has good qualities with respect to most of the tested parameters. The EC, $\mathrm{pH}, \mathrm{OC}$, and $\mathrm{CEC}$ are in the limits required for quality compost; the concentration of AK and AP appear high but TN is low. Among treatments, no significant difference was observed with regard to those parameters. Amending soil with the compost mixtures and synthetic fertilizer did not show significant difference among treatments with regard to those soil parameters after 70 days of application. After the 70 days, a significant decline in soil TN and OC was observed, but no significant variation in other parameters. A significantly high maize crop yield was observed in treatment 50FW50M.

Instead of dumping food waste and creating scavenging opportunity for wild animals and possible health issues for residents, the material should be converted to compost in the 50FW50M proportion. Studies indicate that composting has a low cost and high benefit. The cost benefit for this specific situation should be analyzed in future study and the compost should be tried on other crops besides maize. A credible number of studies report low concentrations of toxic elements in soils and in plants grown in soils amended with compost. For the specific situation in Wondo Genet College of Forestry and Natural Resources, further analysis is recommended.

\section{Methods}

\section{The study area}

The composting experiment was carried out at the Wondo Genet College of Forestry and Natural Resources compound, located $13 \mathrm{Km}$ South West of Shashemene town,
Ethiopia. Wondo Genet is geographically located within $7^{\circ}$ $6^{\prime} \mathrm{N}$ latitude and $38^{\circ} 7^{\prime} \mathrm{E}$ longitudes. The compound lies within altitudinal range 1800-2580 masl. The experiment site is located at $1818 \mathrm{~m}$ above sea level and experiences a bimodal rainfall distribution with $1244 \mathrm{~mm}$ annual precipitation. The mean monthly temperature is $19.5^{\circ} \mathrm{C}$, with mean monthly maximum temperature of $26.3^{\circ} \mathrm{C}$ and mean monthly minimum temperature of $12.4^{\circ} \mathrm{C}$. The 1000 ha of college property possess thick natural forest with dominant indigenous species including Celtis africana, Cordia africana, Croton macrostachys, Albizia gumifera, Podocarpus gracilar, and Milletia. The college also has various farming areas including plantation forests, dairy farming, coffee and sugarcane production, and apiculture. Native wildlife such as Sus scrofa, ape, monkey, aner, bush back, etc. are found in the forest surrounding the academic and residential areas.

The prepared compost was applied to maize crops in Gotu Onama kebele ${ }^{1}$ about $3 \mathrm{~km}$ from the college. The field site has a similar climate as the college. The field site soil is classified as sandy clay loam texture.

\section{Methodology}

Food waste was collected from college cafeterias (student lounge, student cafeteria, staff lounge, and Bungalow lodge) daily, for three weeks. The food wastes majorly comprise unused part of onion, potato, cabbage etc. Non-biodegradable materials such as plastic, foil, wrappers, broken bottles and cans were removed. The collected biodegradable food waste was crushed (when required) and mixed to improve uniformity.

Pit method was used for preparing compost in four treatments as specified in Table 5 below:

Each treatment was replicated 3 times. The decomposing material in each pit ( $1 \mathrm{~m}$ long*0.5 $\mathrm{m}$ wide $0.7 \mathrm{~m}$ deep) was mixed (turned) weekly to provide uniform processing of all the material. The composting process was monitored for six months.

After the composting process, one composite sample was collected from each treatment and their replications (4 treatments *3 replications). The samples were air dried, crushed and passed through a $2 \mathrm{~mm}$ sieve. The following parameters were analyzed in JIJE Analytical Testing Service Laboratory, Addis Ababa, following the methods indicated in Table 6 below.

Table 5 Treatments indicating the proportion of decomposing materials

\begin{tabular}{ll}
\hline Treatment & Treatment description \\
\hline 100FW & $100 \%$ food waste by volume \\
75FW25M & $75 \%$ food waste mixed with $25 \%$ cattle manure by volume \\
50FW50M & $50 \%$ food waste mixed with $50 \%$ cattle manure by volume \\
25FW75M & $25 \%$ food waste mixed with $75 \%$ cattle manure by volume \\
\hline
\end{tabular}


Table 6 The analyzed parameters and the laboratory methods

\begin{tabular}{|c|c|c|}
\hline $\mathrm{S} / \mathrm{N}$ & Parameters & Method applied to analyze the parameter \\
\hline 1 & $\mathrm{pH}$ & Potentiometric - Water Extract. \\
\hline 2 & Electric conductivity (EC) & Conductivity - Water Extract. \\
\hline 3 & Available phosphorous (AP) & Olsen et.al. \\
\hline 4 & Available potassium (AK) & $\begin{array}{l}\text { Ammonium acetate extraction, flame } \\
\text { photometry for determination. }\end{array}$ \\
\hline 5 & Organic carbon (OC) & Walkley - Black \\
\hline 6 & $\begin{array}{l}\text { Cation Exchange } \\
\text { Capacity (CEC) }\end{array}$ & $\begin{array}{l}\text { Sodium equivalent by flame } \\
\text { photometer. }\end{array}$ \\
\hline 7 & Total nitrogen (TN) & Kjeldahl \\
\hline
\end{tabular}

The dynamics of those nutrients was analyzed using one-way ANOVA.

The compost from each treatment and replication was weighed to decide the proper field application land area. To test crop performance, a volunteer farmer in Gotu Onama kebele was recruited. Soil samples were collected from the farmer's agricultural field prior to compost applications. The samples were collected from each expected treatment and its replications plot. Each sample was collected from $0-30 \mathrm{~cm}$ soil depth. The EC, $\mathrm{pH}, \mathrm{AK}$, $\mathrm{AP}, \mathrm{TN}, \mathrm{OC}$, and CEC were analyzed in the laboratory following the methods explained in Table 6. The analysis was carried out to obtain baseline information on soil quality before field treatment.

The compost was applied to a field of maize (variety P.H B.p2859W/Shala), which the volunteer farmer was planning to grow that season. In addition to the compost, a commercial fertilizer was also included as a plot in the field test as well as a control area. The treatments (Table 7) were applied in Complete Random Block Design (CRBD) and each plot covers $6 \mathrm{~m}^{\circ}$ area. Land preparation consisted of the traditional practices used in area. The crop was sown in rows and the compost/ fertilizer placed in the furrow where the seeds were sown. Compost was buried just below soil surface above the seeds.

Table 7 Treatments applied on crop and its description

\begin{tabular}{|c|c|}
\hline Treatment & Description of treatment \\
\hline 1 & $100 \%$ food waste by volume decomposed for six months \\
\hline 2 & $\begin{array}{l}75 \% \text { food waste mixed with } 25 \% \text { cow dung by volume } \\
\text { decomposed for six months }\end{array}$ \\
\hline 3 & $\begin{array}{l}50 \% \text { food waste mixed with } 50 \% \text { cow dung by volume } \\
\text { decomposed for six months }\end{array}$ \\
\hline 4 & $\begin{array}{l}25 \% \text { food waste mixed with } 75 \% \text { cow dung by volume } \\
\text { decomposed for six months }\end{array}$ \\
\hline 5 & $\begin{array}{l}\text { Commercial fertilizer of recommended rate (DAP: } 100 \text { kg/ha; } \\
\text { and Urea: } 50 \mathrm{~kg} / \mathrm{ha} \text { ) }\end{array}$ \\
\hline 6 & Control without commercial synthetic or compost \\
\hline
\end{tabular}

The compost in treatments 2-5 was applied at rate of 20 ton/ha. Each treatment was replicated three times. Weeding and cultivations was carried out as required.

Soil samples after treatment were collected from each treatment and replication plots from a depth of $0-30 \mathrm{~cm}$ from each study plot. The samples were collected 70 days after sowing when the maize was in the flowering stage. During this stage it is expected that a high proportions of the required nutrients (about $75 \% \mathrm{~N}, 74 \%$ of $\mathrm{P}$ and $85 \%$ of $\mathrm{K}$ ) has been taken up by the plant (Mengel, 1995). The soil samples were air dried, passed through a $2 \mathrm{~mm}$ sieve and analyzed as described in Table 6. These results were compared to pre-treatment properties using $t$-test in SPSS software version 20. The maize was harvested and manually threshed at physiological maturity (Tulema et al. 2007) and weighed. The grain yield was compared using one way ANOVA.

\section{Endnotes}

${ }^{1}$ kebele is the smallest administrative unit of Ethiopia.

\section{Abbreviations}

25FW75M: $25 \%$ food waste and $75 \%$ cattle manure; 50FW50M: $50 \%$ food waste and $50 \%$ cattle manure; 75FW25M: $75 \%$ food waste and $25 \%$ cattle manure; 100FW: $100 \%$ food waste; AK: Available potassium; AP: Available phosphorus; $\mathrm{CO}_{2}$ : Carbon dioxide; $\mathrm{CEC}$ : Cation exchange capacity; $\mathrm{CH}_{4}$ : Methane; EC: Electric conductivity; IPCC: Intergovernmental Panel on Climate Change; K: Potasium; N: Nitrogen; $\mathrm{N}_{2} \mathrm{O}$ : Nitrous oxide; OC: Organic carbon; P: Phosphorus; $\mathrm{pH}$ : Power of hydrogen; TN: Total nitrogen.

\section{Competing interests}

The authors declare that there is no competing interests.

\section{Authors' contributions}

KW: participated in designing the research idea, field experiments design, experiment monitoring, data collection, data analysis, intrepretation and report writing; BM: participated in designing the research idea, field experiment design, experiments monitoring, and data collection. Both authors read and approved the final manuscript.

\section{Authors' information}

Kebede Wolka: Assistant professor at Hawassa University, Wondo Genet College of Forestry and Natural Resources. He mainly teaches and undertakes research on soil, soil erosion, soil and water conservation and watershed management. He published 8 articles mainly in international journals and few others are in peer review process. He has been serving as head of school of natural resources and environmental studies.

Bezashwork Melaku: Lecturer at Hawassa University, Wondo Genet College of Forestry and Natural Resources. She teaches and undertakes research on environment and development.

\section{Acknowledgement}

This research was financially supported by Hawassa University, Wondo Genet College of Forestry. The authors would like to thank Bob Sturtevant, Colorado State University, for language editing. Authors also thank the anonymous reviewers for constructive comments.

Received: 4 March 2015 Accepted: 15 May 2015

Published online: 27 May 2015

\section{References}

Alexander R (2001) Field guide to compost use. The US composting council. Accessed on line: 5/1/2015. http://compostingcouncil.org.

Anderson JK, Boldrin A, Christensen TH, Scheutz C (2012) Home Composting as an Alternative Treatment Option for Organic Household Waste in Denmark: 
An Environmental Assessment Using Life Cycle Assessment-Modelling.". Waste Manag 32:31-40

Barral Silva MT, Menduíña AM, Cendón Seijo Y, Viqueira DF (2007) Assessment of municipal solid waste compost quality using standardized methods before preparation of plant growth media. Waste Manage Reearch 25:99-108

Benjawan L, Sihawong S, Chayaprasert W (2015) LiamlaemW, 2015 Composting of Biodegradable Organic Waste from Thai Household in a Semi-Continuous Composter. Compost Science \& Utilization 23:11-17

Brady NC, Weil RR (2002) Nature and properties of soils, 13th edn. Prentice Hall, Upper Saddle River, New Jersey, USA

Chari KM, Ravi MV (2013) Evaluation of Quality and Nutrient Status of Enriched Compost. IOSR Journal of Agriculture and Veterinary Science 6(2):19-23

Colon J, Blancoc JM, Gabarrella X, Artolaa A, Sanchez A, Rieradevall J et al (2010) Environmental Assessment of Home Composting. Resour Conserv Recycl 54:893-904

D'Hose T, Cougnon M, De Vliegher A, Willekens K, Van Bockstaele E, Rehe D (2012) Farm Compost application:Effects on Crop Performance. Compost Science \& Utilization 20(1):49-56

Edwerds S, Arefayne A, Hailu A, Tewoldeberhan G (2007) Impact of compost use on crop yields in Tigray, Ethiopia. Natural Resource Management and Environment Department. Food and Agriculture Organization of the United Nations (FAO), Rome

Eichler-Löbermann B, Köhne S, Köppen D (2007) Effect of organic, inorganic, and combined organic and inorganic $P$ fertilization on plant $P$ uptake and soil $P$ pools. J Plant Nutr Soil Sci 170:623-628

Faridullah NZ, Alam A, Irshad M, Sabir MA (2014) Distribution and Evaluating Phosphorus, Potassium, Calcium and Magnesium in the Fresh and Composted Poultry Litter. Bulgarian Journal of Agricultural Science 20(6):1368-1374

Gajalakshmi S, Abbasi SA (2008) Solid Waste Management by Composting:State of the art. Environ Sci Technol 38(5):311-400

Giannakis GV, Kourgialas NN, Paranychianakis NV, Nikolaidis NP, Kalogerakis N (2014) Effects of Municipal Solid Waste Compost on Soil Properties and Vegetables Growth. Compost Science \& Utilization 22:116-131

Hartl W, Erhart E (2005) Crop nitrogen recovery and soil nitrogen dynamics in a 10-year field experiment with biowaste compost. J Plant Nutr Soil Sci 168:781-788

Hepperly P, Lotter D, Ziegler Ulsh C, Seidel R, Reider C (2009) Compost, Manure and Synthetic Fertilizer Influences Crop Yields, Soil Properties, Nitrate Leaching and Crop Nutrient Content. Compost Science \& Utilization 17(2):117-126

Horneck DA, Sullivan DM, Owen JS, Hart JM (2011) Soil Test Interpretation Guide

Hseu ZY (2004) Evaluating heavy metal contents in nine composts usingfour digestion methods. Bioresour Technol 95:53-59

Hussain SS, Ara T, Ahmad FR, Gani G, Hussain N, Hussain M (2015) S. R. Dar3Quality Evaluation of Different Forms of Compost and Their Effect in Comparison with Inorganic Fertilizers on Growth and Yield Attributes of Wheat (Triticum aestivum L.). J Agric Sci 7(1):154-160

Lillywhite RD, Dimambro ME, Rahn CR (2009) Effect of Five Municipal Waste Derived Composts on a Cereal Crop. Compost Science \& Utilization 17(3):173-179

Mengel D (1995) Roots, growth and nutrient uptake. Accessed on line: 1/3/2015 www.agry.purdue.edu/ext/pubs/agry-95-08.pdf

Miller JJ, Beasley BW, Drury CF, Larney FJ, Hao X (2015) Influence of Long-Term (9 yr) Composted and Stockpiled Feedlot Manure Application on Selected Soil Physical Properties of a Clay Loam Soil in Southern Alberta. Compost Science \& Utilization 23:1-10

Mrabet L, Belghyti D, Loukili A, Attarassi B (2012) Effect of household waste compost on the productivity of maize and lettuce. Agricultural Science Research Journals 2(8):462-469

Nguyen TH, Shindo H (2011) Effects of different levels of compost application on amounts and distribution of organic nitrogen forms in soil particle size fractions subjected mainly to double cropping. Agric Sci 2(3):213-219

Oberholzer Han R, Leifeld J, Mayer J (2014) Changes in soil carbon and crop yield over 60 years in the Zurich Organic Fertilization Experiment, following land-use change from grassland to Cropland. J Plant Nutr Soil Sci 177:696-704

Reeves DW (1997) The role of soil organic matter in maintaining soil quality in continuous cropping systems. Soil Tillage Research 43:131-167

Roberta CB (1999) Protecting Wildlife from Trash. EnvironmentalChemistry.com. 1999. Accessed on-line: 1/3/2015 http://EnvironmentalChemistry.com/yogi/ hazmat/articles/trash.html.
Rosen CJ, Bierman PM (2005) Nutrient Management for Fruit \& Vegetable Crop Production: using manure and compost as nutrient sources for vegetable crops. University of Minnesota, college of agricultural, food and environmental sciences, extension services.

Szilveszter B, Alaeddin E, Hamed AA, Hamuda HE, Bayoumi AF, György F (2012) Effects of compost application on soil fertility of a Luvisol from Gödöllő (Hungary). Arch Agron Soil Sci 58(sup1):S103--S106

Tulema B, Aune JB, Breland TA (2007) Availability of organic nutrient sources and their effects on yield and nutrient recovery of tef (Eragrostis tef (Zucc.) Trotter) and on soil properties. J Plant Nutr Soil Sci 170:543-550

\section{Submit your manuscript to a SpringerOpen ${ }^{\circ}$ journal and benefit from:}

- Convenient online submission

- Rigorous peer review

- Immediate publication on acceptance

- Open access: articles freely available online

- High visibility within the field

- Retaining the copyright to your article

Submit your next manuscript at $>$ springeropen.com 